\title{
A new species of Coccus (Hemiptera, Coccoidea, Coccidae) from China
}

\author{
Fang Wang ${ }^{1, \dagger}$, Ji-Nian Feng ${ }^{1, \neq}$ \\ I Key Laboratory of Plant Protection Resources and Pest Management, Ministry of Education, Entomological \\ Museum, College of Plant Protection, Northwest A\& F University, Yangling, Shaanxi Province, 712100, China. \\ † urn:lsid:zoobank.org:author:8964C2B8-302E-473D-8089-B07382D90FBO \\ ‡urn:lsid:zoobank.org:author:16913882-73AC-47FE-9C89-5B61FC961524 \\ Corresponding author: Ji-Nian Feng (jinianf@nwsuaf.edu.cn)
}

Academiceditor:R. Blackman | Received26September 2012|Accepted 19November 2012|Published 22 November 2012

urn:lsid:zoobank.org:pub:0F8D65BA-4E23-4CA4-BCA4-0542288761AB

Citation: Wang F, Feng J-N (2012) A new species of Coccus (Hemiptera, Coccoidea, Coccidae) from China. ZooKeys 244: 59-65. doi: 10.3897/zookeys.244.4045

\section{Abstract}

A new species of soft scale, Coccus multisetus Wang \& Feng, sp. n. is described and illustrated from Yunnan, China. A key to adult females of all Coccus known from China is provided.

\section{Keywords}

Hemiptera, Coccoidea, soft scale, new species, China

\section{Introduction}

The Coccidae or soft scales (Hemiptera: Sternorrhyncha: Coccoidea) is the third largest family of the Coccoidea after the Diaspididae (armored scales) and the Pseudococcidae (mealybugs) (Ben-Dov et al. 2012). Soft scales are widespread throughout the world and many of them are important pests on agricultural and horticultural crops and ornamental plantings (Henderson and Hodgson 2005), such as Ceroplastes rubens Maskell, C. japonicus Green and Didesmococcus koreanus Borchsenius. Nonetheless, 
some species are very beneficial to man, such as Ericerus pela (Chavannes), whose wax provides an important raw material for many industries (Tang 1991).

Coccus is the oldest genus within the Coccidae (Avasthi and Shafee 1991). The genus was proposed by Linnaeus in 1758, with Coccus hesperidum Linnaeus as its type species, and belongs to the tribe Coccini, subfamily Coccinae (Hodgson 1994). Coccus is a very large genus present in all zoogeographical regions (Hodgson 1994) but is in urgent need of revision. Hitherto, coccidologists have listed about 94 species in this genus (Williams and Ben-Dov 2009, Martin and Lau 2011, Ben-Dov et al. 2012), of which 10 have been recorded from China (Takahashi 1932, Tao et al. 1983, Tang 1991, Martin and Lau 2011). Moreover, some Coccus species are pests of horticultural and ornamental plants in China (Yang 1982).

In this paper, we describe and illustrate the adult female of a new species, Coccus multisetus Wang \& Feng, sp. n. This new species shares certain characteristics with C. formicarii (Green), which has previously been placed in Taiwansaissetia Tao et al., 1983, but that genus has now been synonymised with Coccus (Lin et al. in press). A key is provided for separation of the 11 species of Coccus currently known from China.

\section{Materials and methods}

The specimens were all immersed in 75\% ethanol, and then prepared and mounted mainly according to the method of Hodgson and Henderson (2000). The terminology used in the description is mainly that of Hodgson (1994). Characters were examined under a Nikon compound microscope. An Olympus BH-2 stereoscopic microscope was used for drawing. The illustrations show adult female specimens, with the dorsum depicted on the left side and the venter on the right side, with enlargements of important characters shown around the main illustration. All measurements were made using the software NIT-Elements D and were given in micrometers $(\mu \mathrm{m})$ or millimeters $(\mathrm{mm})$.

All specimens are deposited in the Entomological Museum of Northwest A\&F University, Yangling, Shaanxi, China (NWAFU).

\section{Taxonomy}

Genus Coccus Linnaeus, 1758

http://species-id.net/wiki/Coccus

Coccus Linnaeus, 1758: 455-457. Type species: Coccus hesperidum Linnaeus, 1758.

Generic diagnosis. Adult female. Body oval, elongate or pyriform; usually flat, moderately convex, or nearly hemispherical. Dorsum. Derm membranous; gradually in- 
creasing in thickness during ageing. Dorsal setae setose, spinose, clavate or cylindrical. Dorsal tubular ducts and dorsal submarginal tubercles present or absent. Preopercular pores present or absent, varying in number and shape. Anal plates together quadrate. Anal ring with 6 or 8 setae. Margin. Marginal setae simple to branched; stigmatic clefts deep or shallow, each with 2-8 stigmatic spines. Venter. Antennae 2-8 segmented. Legs well developed or reduced; with or without a tibio-tarsal articulatory sclerosis. Spiracular disc-pores with 5 loculi. Pregenital disc-pores mainly with 10 loculi, present around anal opening, or extending anteriorly, even as far as head. Ventral tubular ducts present or absent; when present located medially, or forming a sparse or dense submarginal band.

\section{Key to adult female Coccus known from China}

1 Body elongate, tapering at both anterior and posterior ends; antennae 6 segmented; with a dense submarginal band of ventral tubular ducts

C. takanoi Takahashi

Characters not in the above combination.............................................. 2

2 Dorsal submarginal tubercles present.................................................

- Dorsal submarginal tubercles absent .................................................

3 Antennae 2 segmented; interantennal setae absent.... C. cambodiensis Takahashi

- $\quad$ Antennae 6-8 segmented; interantennal setae present.... Dorsal tubular ducts present; the outer ductules of dorsal tubular ducts very wider than those on venter. Dorsal tubular ducts present or absent; if present, the outer ductules of dorsal tubular ducts narrower than those on venter. Marginal setae mostly fine and not branched C. hesperidum $\mathrm{L}$. Marginal setae mostly branched. Body elongate oval; ventral tubular ducts present medially between the middle and hind legs. Body broadly oval; ventral tubular ducts sparsely scattered over venter, and not restricted to the median area. .. C. discrepans (Green)

9 Dorsal setae spinose C. pseudomagnoliarum (Kuwana) Dorsal setae setose With 3 pairs of pregenital setae; without a submarginal band of ventral tubular ducts

With 2 pairs of pregenital setae; with a sparse submarginal band of ventral tubular ducts. 


\section{Coccus multisetus Wang \& Feng, sp. n.}

urn:lsid:zoobank.org:act:F00857A0-3484-4537-96EC-AD2C10B67F15

http://species-id.net/wiki/Coccus_multisetus

Figure 1

Material examined. Holotype: adult female. CHINA, Yunnan Prov., Natural reserve of Mengyang. 17.v.2012, on Mangifera indica (Anacardiaceae), Fang Wang (NWAFU).

Paratypes: 3 adult females, the data same as holotype.

Adult female. Unmounted material. Convex, sometimes nearly hemispherical; dark brown with a pale brown marginal band. Dried materials hard, bearing many ridges from median longitudinal ridge.

Mounted material. Body broadly oval, 2.6-3.6 mm long, 2.0-2.8 mm wide. Anal cleft about $1 / 7$ th of body length. Stigmatic clefts distinct.

Dorsum. Derm membranous, with cell-like clear areas. Dorsal setae setose, slender, each 16-30 $\mu \mathrm{m}$ long, with well-developed basal sockets, sparsely distributed over dorsum but absent from median area. Dorsal pores circular, each with a dark rim and about $1-2 \mu \mathrm{m}$ in diameter, sparsely distributed on dorsum. Dorsal microducts, each with a very short outer ductule and a normal inner filamentous ductule, present in each cell-like area. Dorsal tubular ducts and dorsal submarginal tubercles absent. Preopercular pores, each 3-4 $\mu \mathrm{m}$ in diameter, present in an elongate group anterior to anal plates. Anal plates each broadly triangular, 152-169 $\mu \mathrm{m}$ long, 90-98 $\mu \mathrm{m}$ wide; anterior and posterior margins subequal in length, outer angle nearly a right-angle; each plate with 6 or 7 apical or subapical setae, each 9-16 $\mu \mathrm{m}$ long. Ano-genital fold with 2 pairs of long setae, each 45-60 $\mu \mathrm{m}$ long, present along anterior margin plus 3 pairs of setae, each $28-40 \mu \mathrm{m}$ long, along each lateral margin. Anal ring subcircular, with 2 or 3 rows of translucent pores and 6 anal ring setae.

Margin. Marginal setae, each 18-29 $\mu \mathrm{m}$ long, setose, fine, straight or curved, all with well-developed basal sockets; with 40-57 setae between anterior clefts, 14-18 setae between each anterior cleft and posterior cleft, and 32-43 setae between each posterior cleft and anal cleft. Stigmatic clefts shallow, each with 3-8 stigmatic spines: with 3 median spines, each $22-38 \mu \mathrm{m}$ long, blunt, stout, larger than more lateral spines and broadly based; lateral spines, each 8-19 $\mu \mathrm{m}$ long, blunt, smaller and with pointed apices. Eyespots not found.

Venter. Derm entirely membranous. Antennae 8 segmented, each 260-284 $\mu \mathrm{m}$ long; third segment longest; with 2 pairs of interantennal setae, each $20-38 \mu \mathrm{m}$ long. Clypeolabral shield 206-217 $\mu \mathrm{m}$ long, 166-190 $\mu \mathrm{m}$ wide; labium 102-115 $\mu \mathrm{m}$ long, 96-109 $\mu \mathrm{m}$ wide, with 4 setae $(24-28 \mu \mathrm{m})$ on each side. Legs rather slender; each trochanter with a pair of sensory pores on each side and a single long seta on its ventral surface; each leg with a weak articulation between tibia and tarsus, but with no articulatory sclerosis; tarsal digitules both slender, knobbed and longer than claw digitules, claw digitules both with knobbed apices, but one smaller than the other; claws without a denticle; dimensions of metathoracic leg: coxa 60-75 $\mu \mathrm{m}$, trochanter+femur 132$160 \mu \mathrm{m}$, tibia $80-98 \mu \mathrm{m}$ and tarsus $68-87 \mu \mathrm{m}$. With 2 pairs of long pregenital setae 


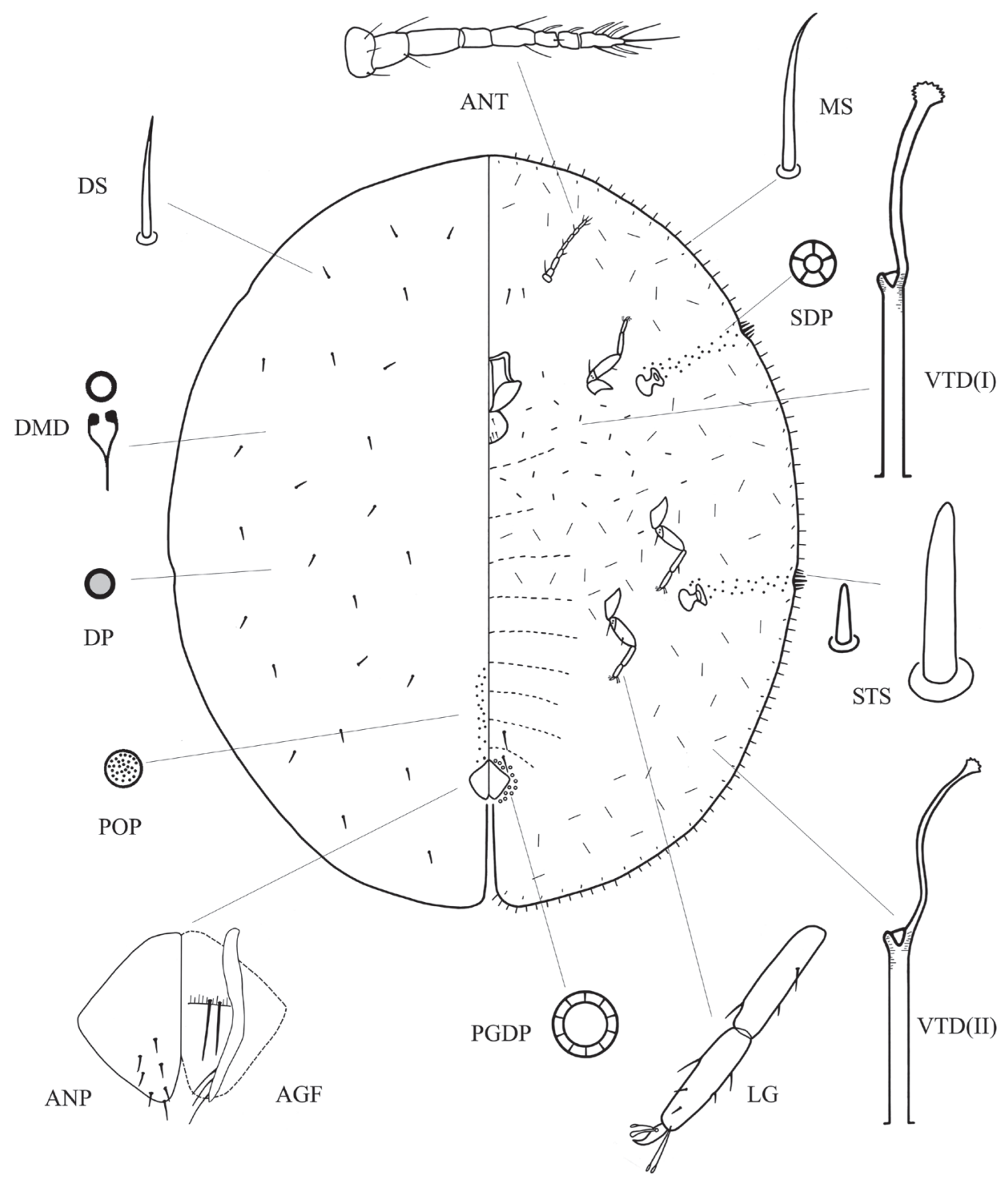

Figure I. Coccus multisetus sp. n. ANT antenna; ANP anal plate; AGF ano-genital fold; DMD dorsal microduct; DP dorsal pore; DS dorsal seta; LG tibio-tarsus of hind leg; MS marginal seta; PGDP pregenital disc-pore; SDP spiracular disc-pore; STS stigmatic spines; VTD(I) ventral tubular duct of type 1); VTD(II) ventral tubular duct of type 2).

in both segments VI \& VII, each 48-66 $\mu \mathrm{m}$ long; submarginal setae present in a single row, each 5-12 $\mu \mathrm{m}$ long; other ventral setae slender, each 6-12 $\mu \mathrm{m}$ long, quite sparsely distributed. Spiracles normal. Spiracular disc-pores each about 4-6 $\mu \mathrm{m}$ in diameter and mainly with 5 loculi; present in a band 2-4 pores wide between stigmatic cleft and each spiracle; with $26-38$ pores in each anterior spiracle band and 34-44 pores in each posterior band. Pregenital disc-pores each about 5-7 $\mu \mathrm{m}$ in diameter and mainly 
with 10 loculi; present around anal opening. Ventral tubular ducts of 2 types: 1) a duct with an elongate outer ductule, each about 15-24 $\mu \mathrm{m}$ long and 2-4 $\mu \mathrm{m}$ wide; an inner ductule about half width of outer ductule, each about 16-24 $\mu \mathrm{m}$ long and 2-3 $\mu \mathrm{m}$ wide; and with a well-developed terminal gland, each about 3-5 $\mu \mathrm{m}$ wide; present medially on head posterior to mouthpart and on prothorax; and 2) a duct with an elongate outer ductule, each about 18-24 $\mu \mathrm{m}$ long and 2-4 $\mu \mathrm{m}$ wide; an inner ductule slightly longer than outer ductule and narrower than that of type 1), each about 20-26 $\mu \mathrm{m}$ long and 1-2 $\mu \mathrm{m}$ wide; and with a well-developed terminal gland, each about 2-3 $\mu \mathrm{m}$ wide; forming a sparse submarginal band and also present medially on meso- and metathorax, extending laterally and mingling with type 1) ducts.

Distribution. China (Yunnan).

Etymology. The species epithet multisetus refers to the many setae on the dorsal surface of the anal plates.

Comments. Adult females of $C$. multisetus are superficially similar to those of $C$. formicarii (Green), which also had been collected in the nests of ants on Mangifera indica. The new species and C. formicarii (data from Hodgson, 1994, as Taiwansaissetia formicarii) share some distinct characteristics: 1) presence of setose dorsal setae; 2) lack of a tibio-tarsal articulatory sclerosis; 3) pregenital disc-pores restricted to around anal opening, and 4) lack of dorsal tubular ducts and submarginal tubercles. These distinct characteristics of the two species differ from those of typical Coccus, and might be due to their myrmecophilous habit and adaptation to living inside ant nests (Lin et al. in press).

However, C. multisetus can be distinguished by the possession of the following features (character states of $C$. formicarii in brackets): 1) 2 pairs of pregenital setae present (3 pairs); 2) 6 or 7 apical or subapical setae on each plate (3 or 4); 3) a submarginal band of ventral tubular ducts (absent); 4) dorsal setae nearly absent on median area (present), and 5) absence of a denticle on the claw (present). Although Hodgson (1994), when studying slide-mounted specimens considered to be T. formicarii, found their morphology to be rather variable, he noted none of the differences mentioned here, other than the presence of the denticle on the claw. It is thus considered that $C$. multisetus is an undescribed species which may be close to $C$. formicarii.

\section{Acknowledgements}

We are grateful to Prof. Wenzhe Wu (Department \& Graduate Institute of Entomology, National Taiwan University) and Dr. Gillian Watson (Plant Pest Diagnostics Branch, California Department of Food \& Agriculture, USA) for providing valuable papers. We give our sincere thanks to Dr. Yanbo Lin (School of Biological Sciences, The University of Queensland, Australia), who made valuable comments and suggestions for Taiwansaissetia. We also wish to thank Dr. John Richard Schrock (Emporia State University, USA) for language correction of the manuscript. This study is supported by the National Natural Science Foundation of China (Grant No. 30870324). 


\section{References}

Avasthi RK, Shafee SA (1991) Revision of the genus Coccus Linn. in India (Insecta, Homoptera, Coccidae). Journal of the Bombay Natural History Society 88(3): 329-348.

Ben-Dov Y (2012) ScaleNet: a database of the scale insects of the world. http://www.sel.barc. usda.gov/scalenet/scalenet.htm [accessed 18. August. 2012]

Henderson RC, Hodgson CJ (2005) Two new species of Umbonichiton (Hemiptera: Sternorrhyncha: Coccoidea: Coccidae) from New Zealand. Zootaxa 854: 1-11.

Hodgson CJ (1994) The Scale Insect Family Coccidae: An Identification Manual to Genera. CAB International, Wallingford, Oxon, UK, 639 pp.

Hodgson CJ, Henderson RC (2000) Coccidae (Insecta: Hemiptera: Coccoidea). Fauna of New Zealand 41: 1-264.

Linnaeus C (1758) Insecta. Hemiptera. Coccus. Systema Naturae. Ed. X, Trformata, Tomus I. Laurentii Salvii, Holmiae, 823pp.

Lin YP, Takumasa K, Gullan PJ, Lin GC (in press) Delimiting genera of scale insects: molecular and morphological evidence for synonymising Taiwansaissetia Tao, Wong \& Chang with Coccus Linnaeus (Hemiptera: Coccoidea: Coccidae). Systematic Entomology.

Martin JH, Lau CSK (2011) The Hemiptera-Sternorrhyncha (Insecta) of Hong Kong, China-an annotated inventory citing voucher specimens and published records. Zootaxa 2847:1-122.

Takahashi R (1932) Records and descriptions of the Coccidae from Formosa. Part 2. Journal of the Society of Tropical Agriculture Formosa 4: 41-48.

Tang FT (1991) The Coccidae of China. Shanxi United Universities Press, Taiyuan, China, 377 pp. [In Chinese]

Tao CCC, Wong CY, Chang YC (1983) Monograph of Coccidae of Taiwan, Republic of China (Homoptera: Coccoidea). Journal of Taiwan Museum 36: 57-107.

Williams DJ, Ben-Dov Y (2009) A review of species names combined with the genus name Coccus Linnaeus (Hemiptera: Sternorrhyncha: Coccoidea). Zootaxa 2285: 1-64.

Yang PL (1982) General classification of scale insects in China. Shanghai Science \& Technology, Shanghai, 425 pp. [In Chinese] 